*Advogado. Mestre em Direito Ambiental e Desenvolvimento Sustentável na Escola Superior Dom Helder Câmara. Especialista em Direito Tributário pela Fundação Getúlio Vargas. Graduado em Direito pela Faculdade de Direito do Vale do Rio Doce.

E-mail: leonardodegusmao. adv@gmail.com

** Pós-Doutora em Direito Ambiental pela Universidad de Castilla-La Mancha (Espanha). Doutora e Mestre em Direito Constitucional pela UFMG. Próreitora de Pesquisa da Escola Superior Dom Helder Câmara. Professora do Mestrado em Direito Ambiental e Desenvolvimento Sustentável da Escola Superior Dom Hélder Câmara.

E-mail: biaambiental@ yahoo.com.br

\section{A Extensão do Objeto da Ação Popular Ambiental Diante do Microssistema do Processo Coletivo}

\author{
The Extent Of The ObJect From The Environmental \\ Class Action Lawsuit Against The Collective Micro \\ System Process
}

\section{Leonardo Cordeiro de Gusmão* Beatriz Souza Costa**}

Como citar: GUSMÃO, Leonardo Cordeiro de; COSTA, Beatriz Souza. A extensão do objeto da ação popular ambiental diante do microssistema do processo coletivo. Revista do Direito Público, Londrina, v. 14, n. 1, p. 160-178, abr. 2019. DOI: 10.5433/1980-511X2019v14n1p160. ISSN: 1980-511X.

Resumo: A democracia se fortalece pelo exercício da cidadania, consolidando a Soberania Popular por meio da atuação solidária voltada para o bem-estar da coletividade. Só assim será dada máxima eficácia aos direitos fundamentais que compõem a dignidade da pessoa humana. No que se refere ao direito ao meio ambiente ecologicamente equilibrado, a ação popular é de suma importância, devendo seu objeto ser interpretado ampliativamente. Para tanto, deve o intérprete considerar a Teoria do Diálogo das Fontes e aplicar o Microssistema do Processo Coletivo. Será demonstrado, a partir do método jurídico de raciocínio dedutivo com pesquisa qualitativa, descritiva e explicativa, mediante uma análise bibliográfica e documental, o cabimento da ação popular também contra omissão lesiva ao meio ambiente, revelando que seu objeto não se limita ao pedido anulatório de ato lesivo. Discorre-se, após, até a conclusão de que é possível qualquer tipo de tutela - obrigação de fazer, de não fazer e condenação em pagar - eficaz na prevenção ou reparação de danos a direitos difusos, coletivos stricto sensu e individuais homogêneos, que tenham origem em lesão ou ameaça de lesão ao direito fundamental ao meio ambiente ecologicamente equilibrado.

Palavras-chave: Ação popular ambiental. Extensão do objeto. Microssistema do processo coletivo.

Abstract: Democracy gets stronger when citizens exercise their 
rights, such as with the popular vote as a means of upholding society's best interest. Likewise, it's the only practical way that gives maximum effectiveness for fundamental rights as it's also an essential component of human dignity. Furthermore, environmental wellness is also an important right and popular action is necessary in order to guarantee and protect it. Therefore, the interpreter of law needs to understand the 'Theory of the Dialogue of the Sources', and the Micro System Collective Process to better guarantee these rights. Furthermore, with the legal method of deductive reasoning and from the perspective of a qualitative, descriptive and explanatory research, this paper shows that the goal of popular action isn't limited to the withdraw request of the aggrieved party. This leads to the conclusion that it is possible to protect these rights with other legal means equally effective in the prevention or reparation of damages caused by irresponsible acts to diffuse, collective and individual homogeneous rights - all of which originate from an injury or threat of injury to the fundamental right of the wellness of the environment. This paper utilized literature review to better grasp and understand this important theme.

Keywords: Environmental popular action. Extent of the object. Micro system collective process. 


\section{INTRODUÇÃO}

O texto Constitucional assegura a todos o direito ao meio ambiente ecologicamente equilibrado (artigo 225, caput), considerando-o bem de uso comum do povo essencial à manutenção da sadia qualidade de vida e, portanto, à efetivação da dignidade da pessoa humana. Sendo o meio ambiente um bem difuso, a Constituição atribui ao poder público e a toda a coletividade o dever de protegê-lo contra sua exploração irresponsável, na intenção de preservá-lo em boas condições para as futuras gerações (BRASIL, 1988).

Ressalta também que a fonte de todo poder constituído é o povo - soberania popular (artigo $1^{\circ}$, parágrafo único) -, que pode exercê-lo por meio de seus representantes eleitos ou diretamente. Nesse contexto, a cidadania é qualificada como valor fundamental do Estado Democrático de Direito (artigo $1^{\circ}$, caput e inciso II), sendo a formação de uma sociedade solidária considerada um objetivo fundamental (artigo $3^{\circ}$, inciso I) (BRASIL, 1988).

Visando dar efetividade ao exercício da cidadania, a Constituição da República Federativa do Brasil (BRASIL, 1988) disponibiliza aos cidadãos meios de influenciar nas três esferas de poder do Estado - executivo, legislativo e judiciário -, no intuito de garantir a máxima eficácia aos direitos fundamentais (artigo $5^{\circ}, \S 1^{\circ}$ ), tendo em vista que a preservação do núcleo deles é imprescindível ao alcance da dignidade da pessoa humana (artigo $1^{\circ}$, inciso III). A ação popular é um instrumento que tem tal finalidade, sendo que seu exercício depende de uma iniciativa que revela solidariedade do cidadão em relação à coletividade e,segundo a literalidade do artigo $5^{\circ}$, inciso LXXIII, destinase à anulação de ato lesivo ao patrimônio público, à moralidade administrativa e ao meio ambiente e patrimônio cultural.

Tal ação coletiva está regulamentada pela Lei 4.717/65, que por ser anterior à promulgação da Constituição e não ter sofrido a necessária alteração legislativa, delimita como objeto do citado remédio constitucional apenas a proteção ao patrimônio público, não abrangendo a tutela ambiental e nem da moralidade administrativa (BRASIL, 1965). No entanto, doutrina e jurisprudência, consubstanciadas na Teoria do Diálogo das Fontes, reconhecem a existência de um "Microssistema do Processo Coletivo", cujo núcleo normativo é composto pela Lei 8.078/90 (Código de Defesa do Consumidor) (BRASIL, 1990) e Lei 7.347/85 (Lei de ação civil pública) (BRASIL, 1985).

No que se refere precisamente ao direito/dever de preservação do meio ambiente, a Constituição (artigo 225) e a legislação infraconstitucional (BRASIL, 1981) determinam que todos - Estado e coletividade - devem adotar medidas contra a concretização dos riscos de danos ao meio ambiente, seja sua ocorrência certa ou incerta (Princípio da Precaução). Ademais, reconhecem que aquele que degradar o meio ambiente estará obrigado a recuperá-lo, além de reparar os danos causados a terceiros. Ressaltam, pois, que o poluidor ficará sujeito a sanções penais e administrativas, sem prejuízo da responsabilidade civil por todos os danos decorrentes da degradação ambiental.

Pretende-se com o presente artigo, valendo-se do método jurídico de raciocínio dedutivo com pesquisa qualitativa, descritiva e explicativa, mediante uma análise bibliográfica 
e documental, analisar o conteúdo decisório formado no acórdão publicado na apelação cível 1.0672.14.032556-0/001, publicado pelo Tribunal de Justiça de Minas Gerais no dia 17/02/2017, no qual se reconheceu a possibilidade de propositura de ação popular para impugnar omissão lesiva à moralidade administrativa (MINAS GERAIS, 2017).

A partir do citado precedente, discorrer-se-á sobre a real extensão do objeto da ação popular ambiental, averiguando se seu objeto pode ser limitado à declaração de nulidade de ato lesivo ao direito ao meio ambiente equilibrado. Considerando a contextualização ora exposta, passa-se adiante à efetiva análise do ratio decidendi contida no acórdão mencionado no parágrafo anterior.

\section{RATIO DECIDENDI CONSTANTE NO ACÓRDÃO DA APELAÇÃO CÍVEL 1.0672.14.032556-0/001/MG}

Em princípio, faz-se necessário destacar que a apelação cível 1.0672.14.032556-0/001/ MG foi apresentada na intenção de impugnar sentença que extinguiu, sem resolução do mérito, ação popular ajuizada em desfavor do Município de Sete Lagoas/MG. Na petição inicial da ação coletiva o cidadão pediu pela declaração judicial reconhecendo a omissão lesiva à moralidade administrativa por parte da administração pública, uma vez que ao não promover a unificação da bilhetagem eletrônica no sistema de transporte coletivo municipal, deixou de atuar em prol do interesse público, causando prejuízos ao consumidor. Fundamentou seu pedido em lei municipal que determina a realização da unificação, pleiteando também pela imposição de tutela específica obrigando o município a concretizar o mandamento legal.

Ao proferir sua sentença o juízo da Vara da Fazenda e Autarquias da Comarca de Sete Lagoas/MG extinguiu a ação popular sem resolução do mérito, sob o fundamento de que o autor não demonstrou a intenção de proteger o patrimônio público e nem comprovou eventual lesividade aos cofres públicos. Instado a se manifestar em grau recursal, a $2^{\text {a }}$ Câmara Cível do Tribunal de Justiça de Minas Gerais, sob a relatoria do Desembargador Raimundo Messias Júnior, deu provimento à apelação ao concluir que a ação popular é cabível quando a suposta lesão for produto de omissão do ente ou autoridade pública, sendo esta a situação do caso concreto.

$\mathrm{Na}$ fundamentação do acórdão o relator aduziu que por se tratar de instrumento que visa tutelar direitos fundamentais a ação popular não pode ser interpretada restritivamente:

Não se pode esquecer que a ação popular, assim como o mandado de segurança e o mandado de injunção, tem dignidade constitucional de garantia constitucional fundamental e é instrumento de tutela dos direitos primaciais da sociedade, razões pelas quais não é compatível interpretação restritiva a seu respeito. (MINAS GERAIS, 2017).

Nesse contexto, ficou reconhecida a viabilidade da tutela coletiva da moralidade administrativa sem necessidade do autor demonstrar a lesividade ao erário, considerando que o artigo $5^{\circ}$, LXXIII da Constituição possibilita à ação popular impugnar atos comissivos e/ou 
omissivos que sejam lesivos não apenas ao patrimônio público, mas também, de forma autônoma, à moralidade administrativa ou ao meio ambiente. Ao proferir o julgamento, fez-se, ainda, referência a entendimento similar firmado no recurso especial 889.766, julgado pelo Superior Tribunal de Justiça sob a relatoria do Ministro Castro Alves, no qual se afirmou que "A ação popular é o instrumento jurídico que deve ser utilizado para impugnar atos administrativos omissivos ou comissivos que possam causar danos ao meio ambiente" (BRASIL, 2007).

Consoante o art. 5 , LXXIII, da Constituição Federal, qualquer cidadão é parte legítima para propor ação popular que vise anular ato lesivo ao patrimônio público ou de entidade de que o Estado participe, à moralidade administrativa, ao meio ambiente e ao patrimônio histórico e cultural. 2. Tais lesões também podem decorrer de omissão, conforme entendimento firmado pelo Superior Tribunal de Justiça no REsp 889.766/SP (MINAS GERAIS, 2017).

Nesse contexto foi dado provimento ao recurso, determinando o retorno dos autos ao juízo de $1^{\mathrm{a}}$ instância para que fosse promovido o julgamento do mérito da causa. Com isso, o Tribunal de Justiça de Minas Gerais consolidou em precedente judicial amparado pela jurisprudência do Superior Tribunal de Justiça, o entendimento de que é possível a propositura de ação popular tendo como objeto a impugnação de atos comissivos ou omissão lesiva ao patrimônio público, à moralidade administrativa ou ao meio ambiente, não sendo, por consequência, imprescindível a existência de dano ao erário e nem o pedido visando o reconhecimento da nulidade de ato administrativo - este é o ratio decidendi do acórdão.

Atente-se, ademais, que em se tratando de ação popular ambiental que visa impugnar omissão lesiva ao meio ambiente, será juridicamente impossível o pedido de reconhecimento de nulidade, o qual se vincula à prática de um ato comissivo ilegal. Nesse sentido, como primeira premissa à conclusão deste trabalho tem-se a compreensão de que a ação popular ambiental pode ser ajuizada contra quem tenha praticado ato lesivo ao meio ambiente ou que, por ser omisso no cumprimento de sua obrigação, tenha dado causa à lesão.

O precedente judicial assinalado, portanto, deixou claro que a existência de pedido anulatório não é imprescindível à ação popular ambiental, a qual deve ser interpretada de forma ampliativa no intuito de proteger efetivamente o direito fundamental ao meio ambiente equilibrado, mediante a tutela jurídica que se revelar necessária para tanto. A referida interpretação deve prezar pela unidade das normas constitucionais, na forma exposta pelo tópico seguinte.

\section{DO PRINCÍPIO DA UNIDADE DA CONSTITUIÇÃO}

No tópico anterior constatou-se que de acordo com a jurisprudência a ação popular ambiental não pode ser interpretada restritivamente, de modo que seu objeto não fica restrito à anulação de ato lesivo, sendo possível seu ajuizamento também em face de omissão lesiva ao meio ambiente. 
Agora, faz-se necessário realizar uma interpretação sistemática do texto constitucional, no intuito de verificar a adequação de tal entendimento judicial, abordando os princípios constitucionais pertinentes.

Na formação da norma jurídica, especialmente quando o caso concreto exigir a determinação da amplitude de direito e/ou garantia fundamental, o intérprete deve realizar uma interpretação sistemática das normas constitucionais, de modo a preservar a coerência e a integridade do direito, aplicando o Princípio da Unidade da Constituição. Para o alcance dos valores e objetivos constitucionais, portanto, não é suficiente o exercício de uma interpretação puramente literal de determinado enunciado normativo constitucional, em especial quando se tratar de direitos e garantias fundamentais, que demandam uma interpretação ampliativa.

O intérprete norteará sua atuação considerando os valores e objetivos fundamentais trazidos pelo texto constitucional. Assim, deve-se dar ênfase à Soberania Popular (artigo1 ${ }^{\circ}$, parágrafo único da Constituição) de modo a garantir maior alcance ao Princípio da Cidadania (artigo $1^{\circ}$, II, da Constituição), ressaltando a necessidade de se efetivar o Princípio da Solidariedade (artigo $3^{\circ}$, I, da Constituição), em prol dos valores consubstanciados pelo Estado Democrático de Direito (artigo $1^{\mathrm{o}}$, caput, da Constituição), os quais são essenciais à Dignidade da Pessoa Humana (artigo $1^{\circ}$, III, da Constituição) (BRASIL, 1988).

Mister que numa democracia moderna seja garantido ao cidadão o direito de participar de forma relevante das questões de interesse coletivo, garantindo-lhe a possibilidade de interferir nos assuntos públicos, inclusive para se manifestar diretamente sobre determinados temas (plebiscito; referendo; iniciativa popular; audiências públicas), bem como impugnar judicialmente por meio de ação popular, atos ou omissões lesivas ao patrimônio público, à moralidade administrativa ou ao meio ambiente.

Ao fazer referência à Teoria da Democracia Deliberativa, de Jürgen Habermas, Luiza Landerdahl Christmann diz que "O procedimentalismo da Teoria Deliberativa reinsere a dimensão social, colocando o discurso na esfera pública como um meio para atingir decisões coletivas através da participação de uma pluralidade de atores sociais" (CHRISTMANN, 2013, p. 3-4).

Por se tratar de instrumento vinculado ao exercício da cidadania, pode-se dizer que a ação popular é uma garantia fundamental disponibilizada aos cidadãos para fortalecer sua participação no âmbito de uma democracia, possibilitando que eles se insurjam contra atos ou omissões lesivas ao patrimônio público, à moralidade administrativa e ao meio ambiente.

Numa democracia deliberativa a participação cidadã não pode estar limitada ao voto,às deliberações dos representantes eleitos e nem mesmo à realização de manifestações relativas a decisões do Poder Executivo (plebiscito; referendo; audiências públicas), devendo abranger também uma atuação proativa perante o Poder Legislativo (projeto de lei de iniciativa popular) e o Poder Judiciário (ação popular).

Da mesma forma, não basta o reconhecimento do direito formal de participação, devendosedar extensão máxima do Princípio da Cidadania por intermédio de sua efetiva aplicação em situações concretas, sob pena de se suprimir casuisticamente o núcleo de direitos e garantias 
fundamentais, em desrespeito ao mandamento do artigo $60, \S 4^{\circ}$, IV, da Constituição. Vale citar, neste momento, os ensinamentos de José Adércio Leite Sampaio:

[...] o princípio do Estado Democrático de Direito não se consola apenas com a figura da representação política formal, exigindo simultaneamente a participação popular e a colaboração judicial responsável nos exercícios de concretização dos direitos fundamentais. (SAMPAIO, 2003, p. 93).

O artigo 225 da Constituição representa o centro normativo relativo à proteção do meio ambiente ecologicamente equilibrado, de modo que os instrumentos que se prestem a garantir a eficácia de tal direito devem ser interpretados em conformidade com tal dispositivo, dando unidade e coerência às normas constitucionais. Extremamente equivocada, assim, a interpretação meramente literal (restritiva) do artigo $5^{\circ}$, LXXIII, no sentido de que a ação popular deveria, necessariamente, intentar anular ato lesivo ao meio ambiente.

Do corpo do artigo 225 retiram-se os Princípios da Gestão Compartilhada do Meio Ambiente (Participação Popular), da Precaução, da Prevenção e do Poluidor-Pagador, servindo ele também como fundamento para a responsabilidade civil objetiva e integral do agente poluidor, no que tange aos danos decorrentes da degradação ambiental que sua atividade ou inatividade proporcionou.

Nesse sentido, qualquer medida que seja eficiente para impedir a concretização de riscos de danos incertos que possuam fundamento científico razoável, em mitigar ou evitar a ocorrência dos danos certos, ou ainda, que tenha por finalidade a reparação de danos ambientais efetivos e de outros danos que sejam consequência da degradação, são manejáveis através de ação popular ambiental. Vale trazer aos autos, pois, alguns ensinamentos de Luiz Guilherme Marinoni e Daniel Mitidiero:

Em um primeiro momento, poder-se-ia pensar que a ação popular visa à prestação de tutela jurisdicional típica - sua finalidade constitucionalmente marcada delimitaria o âmbito de providências que poderiam ser obtidas mediante seu exercício. É preciso, contudo, ir além da interpretação meramente gramatical. É que a finalidade da ação popular está em tutelar a moralidade administrativa, o meio ambiente e o patrimônio histórico e cultural. Dessa forma, todas as tutelas do direito que podem ser prestadas a esses bens jurídicos podem ser obtidas mediante ação popular. É cabível, por exemplo, obtenção de tutela inibitória que é sabidamente preventiva e em nada se assemelha à anulação - para tutela da moralidade administrativa, do meio ambiente e do patrimônio histórico e cultural mediante ação popular. Uma interpretação mais arejada do sistema processual civil abona semelhante solução (MARINONI; MITIDIERO, 2013, p. 781-782).

Relevante frisar, agora, que o direito fundamental à prestação jurisdicional, constante no artigo $5^{\circ}$, inciso XXXV, da Constituição, não visa apenas garantir o acesso formal à justiça, mas também a adequação e efetividade da tutela jurídica. No ordenamento jurídico brasileiro a 
tutela jurídica é a mais ampla possível, sendo possível a defesa de direitos individuais e coletivos (difusos; coletivos em sentido estrito; individuais homogêneos) (BRASIL, 1988).

Qualquer tutela - seja ela declaratória, inibitória, reparatória ou específica - hábil à preservação e defesa do meio ambiente ecologicamente equilibrado pode ser pleiteada em ação popular ambiental, caso contrário não se estará garantindo efetividade ao instrumento processual e ao direito fundamental.

Da interpretação conjunta do $\operatorname{artigo~} 5^{\circ}, \S 1^{\circ}$ e $\operatorname{artigo~} 225, \S 1^{\circ}$ e incisos, da Constituição, chega-se à conclusão de que o Poder Público está obrigado em todas suas esferas - executiva; legislativa; judiciária - a promover as medidas legalmente hábeis no intuito de proteger e defender de forma eficiente o meio ambiente.

Nessa perspectiva, como segunda premissa pode-se dizer que uma interpretação ampliativa da ação popular ambiental, reconhecendo-se a possibilidade de seu objeto envolver todo tipo de tutela jurídica que se mostre útil à preservação e defesa do direito fundamental ao meio ambiente ecologicamente equilibrado ou à efetiva reparação dos danos decorrentes de degradação ambiental, é mais coerente com a Soberania Popular, com o Estado Democrático de Direito e também com os princípios da cidadania, da solidariedade e da dignidade da pessoa humana.

A interpretação restritiva - limitando o objeto da ação popular à invalidação de atos comissivos lesivos ao meio ambiente -, viola o direito fundamental à prestação jurisdicional eficiente, importando numa proteção insuficiente. Isso porque retiraria efetividade da ação popular ambiental ao restringir de forma inconveniente o exercício da cidadania, na contramão do ideal de uma democracia participativa. Urge a necessidade, agora, de analisar quais normas legais podem reger a ação popular, tendo em vista sua essencialidade à elucidação da problemática acerca da extensão de seu objeto.

\section{TEORIA DO DIÁLOGO DAS FONTES E APLICAÇÃO DO MICROSSISTEMA DO PROCESSO COLETIVO À AÇÃO POPULAR AMBIENTAL}

Até o momento se evidenciou que de acordo com a jurisprudência a ação popular ambiental deve ser interpretada de forma ampliativa, não podendo seu objeto ficar restrito apenas à anulação de ato lesivo, sendo possível também a impugnação de omissão lesiva ao meio ambiente por meio da tutela jurídica que se revelar eficiente para tanto.

Destacou-se que o entendimento exposto pelo parágrafo anterior confere coerência e integridade ao direito, uma vez que preza pela unidade constitucional, levando em consideração a centralidade do artigo 225 da Constituição no que se refere à tutela do meio ambiente, além de dar ênfase à Soberania Popular e ao Estado Democrático de Direito, efetivando os princípios da cidadania, da solidariedade e da dignidade da pessoa humana. Preserva-se, ademais, o núcleo do direito fundamental à prestação jurisdicional.

Nesse momento se faz pertinente demonstrar quais são as fontes normativas que dão sustentação à ação popular ambiental, possibilitando a formulação de pedidos de obrigação de 
fazer, de não fazer e de condenação em pagar dinheiro.

Não é incomum, na prática, que diante de um caso concreto o intérprete se depare com lacunas legislativas ou com a convergência de leis capazes de realizar a tutela do bem jurídico ameaçado ou lesado. Compreende-se, atualmente, que quando a situação envolver diversas fontes legislativas - leis especiais e/ou gerais - que possuam campos de aplicação convergentes, as normas serão aplicadas conjuntamente, de forma coerente e coordenada, em conformidade com a Teoria do Diálogo das Fontes. De acordo com Cláudia Lima Marques, somente assim é que se dará coerência ao direito e se preservará sua integridade (MARQUES, 2016, p. 135).

Em relação à aplicabilidade da Teoria do Diálogo das Fontes nas hipóteses de lacunas legislativas ou de convergências de leis, são relevantes as lições dadas pelo ex-ministro do Supremo Tribunal Federal, Joaquim Barbosa, ao proferir seu voto no julgamento da Ação Direta de Inconstitucionalidade 2.591/DF, explicitando que as normas do Código de Defesa do Consumidor são aplicáveis às instituições financeiras:

[...] A Emenda Constitucional 40, na medida em que conferiu maior vagueza à disciplina constitucional do sistema financeiro (dando nova redação ao art. 192) tornou ainda maior esse campo que a professora Cláudia Lima Marques denominou "diálogo entre fontes" - no caso, entre a lei ordinária (que disciplina as relações consumeristas) e as leis complementares (que disciplinam o sistema financeiro nacional). Não há, a priori, por que falar em exclusão formal entre essas espécies normativas, mas, sim, em "influências recíprocas", em "aplicação conjunta das duas normas ao mesmo tempo e ao mesmo caso, seja complementarmente, seja subsidiariamente, seja permitindo a opção voluntária das partes sobre a fonte prevalente". (BRASIL, 2006, p. 351).

Em relação à Lei 4.717/65, criada para regulamentar a ação popular, é imprescindível ponderar novamente que ela ainda não recebeu as adaptações necessárias para ficar condizente com a ampliação do objeto de tal garantia fundamental promovida pelo artigo $5^{\circ}$, LXXIII, da Constituição, não estando apta à realização de uma tutela jurídica adequada e eficiente contra atos e omissões lesivas ao meio ambiente. Nessa perspectiva, cabe ao intérprete adotar a Teoria do Diálogo das Fontes com a finalidade de garantir a efetividade da ação popular e da proteção aos direitos fundamentais por ela tutelados.

Ao aplicar a Teoria do Diálogo das Fontes, a jurisprudência considera que as ações coletivas são regidas por normas contidas no denominado "Microssistema do Processo Coletivo", cujo núcleo é formado pela Lei 8.078/90 (Código de Defesa do Consumidor) (BRASIL, 1990) e pela Lei 7.347/85 (Ação Civil Pública) (BRASIL, 1985). Tal entendimento é exarado em diversos julgados do Superior Tribunal de Justiça, tal como o recurso especial 1.221.254/RS (Min. Rel. Arnaldo Esteves Lima); recurso especial 1.177.453/RS (Min. Rel. Mauro Campbel Marques); agravo regimental no agravo de instrumento 1.249.132/SP (Min. Rel. Luiz Fux). Inclusive, no Informativo de Jurisprudência $\mathrm{n}^{\circ} 0568$ de setembro de 2015, foi publicado o seguinte: 
Ademais, ao se fazer uma interpretação sistemática dos diplomas que formam o microssistema do processo coletivo, seguramente pode-se afirmar que, por força do art. 21 da Lei 7.347/1985, aplica-se o Capítulo II do Título III do Código de Defesa do Consumidor (CDC) à hipótese em análise. Com efeito, a tutela coletiva será exercida quando se tratar de interesses/direitos difusos, coletivos e individuais coletivos, nos termos do art. 81, parágrafo único, do CDC. Assim, necessário observar que, no caso, o interesse tutelado referente à liberação do saldo do PIS/PASEP, mesmo se configurando como individual homogêneo (Lei 8.078/1990), mostra-se de relevante interesse à coletividade, tornando legítima a propositura de ação civil pública pelo Parquet, visto que se subsume aos seus fins institucionais. (REsp 1.480.250-RS, Rel. Min. Herman Benjamin, julgado em 18/8/2015, DJe 8/9/2015 (BRASIL, 2015).

À ação popular, portanto, devem ser aplicadas, desde que não promovam uma desnaturação do instituto jurídico, quaisquer normas do Microssistema do Processo Coletivo que sirvam para dar maior efetividade àquela garantia fundamental e ao bem jurídico tutelado por ela no caso concreto. Seguindo essa linha de raciocínio, o Tribunal de Justiça de Minas Gerais já aplicou normas constantes na Lei 4.717/65 à ação civil pública, devendo a recíproca também ser verdadeira.

O referido raciocínio foi aplicado, por exemplo, no julgamento da apelação cível em reexame necessário de número 1.0342.12.013524-5/002, julgada em 22 de janeiro de 2015 pela Desembargadora Heloísa Combat, por meio da qual se reconheceu a viabilidade de se aplicar a regra da remessa necessária à ação civil pública, fundamentando sua decisão no fato de que sua possibilidade foi garantida em dispositivo constante na Lei de ação popular (4.717/65).

EMENTA: AÇÃO CIVIL PÚBLICA - COMARCA DE ITUIUTABA - RAZÕES DO RECURSO - ART. 514, II, DO CPC - CONHECIMENTO - DIÁLOGO DAS FONTES - AÇÃO POPULAR - REEXAME NECESSÁRIO - INOVAÇÃO DIALETICIDADE-OBSERVÂNCIA-CONCESSÃO DE SERVIÇO PÚBLICO - TERMINAL RODOVIÁRIO - TARIFA PARA USO DE SANITÁRIOS NAS DEPENDÊNCIAS DO TERMINAL - ILEGALIDADE DA COBRANÇA NÃO DEMONSTRADA - REMUNERAÇÃO DO SERVIÇO ESPECÍFICO PREVISÃO CONTRATUAL E LEGAL - RECURSO NÃO PROVIDO $[\ldots]$

Em razão da teoria do diálogo das fontes, tem-se entendido que o microssistema processual da tutela coletiva deve ser regido pela influência subsidiária de seus diversos diplomas, de modo que a remessa necessária assegurada na ação popular pode perfeitamente ser aplicada na ação civil pública. [...] (MINAS GERAIS, 2015).

Muitos outros julgados seguiram o mesmo norte, tais como: 1.0188.15.010614-7/001 (Des. Rel. Corrêa Júnior); 1.0672.14.036495-7/001 (Des. Rel. Mariângela Meyer); 1.0024.10.1708907/007 (Des. Rel. Mariza Porto); 1.0702.13.054159-3/001 (Des. Rel. Oliveira Firmo); 1.0521.12.002272-3/001 (Des. Rel. Yeda Athias); 1.0701.12.031451-6/002 (Des. Rel. Eduardo Andrade).

Para que seja viável ao intérprete a aplicação da Teoria do Diálogo das Fontes, inclusive 
no que tange ao Microssistema do Processo Coletivo, exige-se apenas que a norma utilizada não seja incompatível com a ação coletiva que realiza a tutela do caso concreto. Jamais haverá tal incompatibilidade quando a norma aplicada tiver o condão de dar maior efetividade aos direitos que se pretende preservar ou defender. Merecem destaque, pois, os ensinamentos de Cláudia Lima Marques, especificando a possibilidade do diálogo entre leis especiais:

Em resumo, também entre leis especiais há diálogo das fontes: diálogo sistemático de coerência, diálogo sistemático de complementariedade ou subsidiariedade e diálogo de adaptação ou coordenação. Note-se que raramente é o legislador quem determina esta aplicação simultânea e coerente das leis especiais (um exemplo de diálogo das fontes ordenado pelo legislador é o art. 117 do CDC, que mandou aplicar o Título III do CDC aos casos da anterior Lei da Ação Civil Pública, Lei 7.347/1985 [...] (MARQUES, 2016, p. 147).

Pode-se afirmar que em razão da aplicação da Teoria do Diálogo das Fontes, aplicam-se à ação popular ambiental normas contidas no Microssistema do Processo Coletivo - cujo núcleo é o CDC e a Lei 7.347/85 -, desde que não sejam incompatíveis e tragam maior efetividade à proteção do direito fundamental ao meio ambiente ecologicamente equilibrado. Assim sendo, fazse pertinente uma interpretação conjunta do artigo $1^{\circ}$ da Lei 4.717/65; artigo 11 da Lei. 4.717/65; artigo $3^{\circ}$ da Lei 7.347/85; artigo 81, parágrafo único, I, II e III, do CDC; artigo 83 do CDC; e artigo $84, \S 1^{\circ}$ e $\S 2^{\circ}$, do CDC.

Importante ressaltar, por fim, que de uma interpretação dos artigos $5^{\circ}$, inciso XXXV e 129, inciso III, da Constituição, associada com o artigo $1^{\circ}$, inciso IV, da Lei 7.347/85, retira-se o Princípio da Não Taxatividade do Objeto Material da Ação Coletiva (OLIVEIRA, 2011, p. 134), o qual impede uma limitação dos pedidos cabíveis em ação coletiva - tal como a ação popular.

A terceira premissa, portanto, tem origem na Teoria do Diálogo das Fontes e na aplicação das normas nucleares do Microssistema do Processo Coletivo, consistindo no entendimento de que em sede de ação popular ambiental será possível formular qualquer demanda hábil à tutela ambiental que seja pertinente à ação civil pública - obrigação de fazer; obrigação de não fazer; condenação em pagar dinheiro -, dando máxima eficácia à garantia constitucional e à proteção do direito fundamental ao meio ambiente ecologicamente equilibrado.

Constatado que devido ao Microssistema do Processo Coletivo é possível ao cidadão formular em ação popular ambiental todo tipo de pedido pertinente à proteção do meio ambiente, agora, revela-se indispensável definir os tipos de direitos coletivos (lato sensu) que podem ser tutelados na hipótese de ato ou omissão que represente lesão ou ameaça de lesão ao direito fundamental ao meio ambiente ecologicamente equilibrado, essencial à sadia qualidade de vida.

\section{DA AÇÃO POPULAR AMBIENTAL E A TUTELA DE DIREITOS DIFUSOS, DIREITOS COLETIVOS STRICTO SENSU E DIREITOS INDIVIDUAIS HOMOGÊNEOS}


Apresenta-se neste trabalho a concepção de que a ação popular ambiental pode ser proposta contra ato ou omissão lesiva ao meio ambiente, podendo o cidadão valer-se de qualquer tutela jurídica que se mostre eficaz para proteger e defender o bem jurídico em questão - obrigação de fazer; obrigação de não fazer; condenação em pagar dinheiro -, o qual se caracteriza por ser essencial à sadia qualidade de vida. Nesse contexto, se rechaça a interpretação restritiva da ação popular ambiental, uma vez que seu objeto não pode ser limitado ou vinculado ao pedido de anulação de ato lesivo ao meio ambiente.

Dando continuidade ao raciocínio que se expõe, importa agora frisar quais as espécies de direitos que podem ser abordados na ação popular ambiental, sem que se transponha a noção de possibilidade jurídica do pedido. $\mathrm{O}$ ordenamento jurídico brasileiro admite a tutela de direitos classificados como coletivos (lato sensu). De acordo com o artigo 81, I, II e III do Código de Defesa do Consumidor, esses direitos se subdividem em difusos, coletivos (stricto sensu) e individuais homogêneos.

Art. 81. A defesa dos interesses e direitos dos consumidores e das vítimas poderá ser exercida em juízo individualmente, ou a título coletivo.

Parágrafo único. A defesa coletiva será exercida quando se tratar de:

I - interesses ou direitos difusos, assim entendidos, para efeitos deste código, os transindividuais, de natureza indivisível, de que sejam titulares pessoas indeterminadas e ligadas por circunstâncias de fato;

II - interesses ou direitos coletivos, assim entendidos, para efeitos deste código, os transindividuais, de natureza indivisível de que seja titular grupo, categoria ou classe de pessoas ligadas entre si ou com a parte contrária por uma relação jurídica base;

III - interesses ou direitos individuais homogêneos, assim entendidos os decorrentes de origem comum (BRASIL, 1990).

O tratamento coletivo de tais direitos diminui consideravelmente o risco de decisões contraditórias envolvendo o mesmo fato jurídico, além de propiciar numa redução do volume de processos, promovendo benefícios como a economia processual e a garantia do acesso à justiça.

Considerando as vantagens da tutela coletiva, o Supremo Tribunal Federal reconheceu no julgamento do recurso extraordinário 441.318, julgado em 25 de outubro de 2005 sob a relatoria do Ministro Marco Aurélio, que “[...] tanto quanto possível, considerado o direito posto, deve ser estimulado o surgimento do macroprocesso, evitando-se a proliferação de causas decorrentes da atuação individual”. (BRASIL, 2005)

Agora, faz-se necessário especificar as diferenças entre direitos difusos, direitos coletivos stricto sensu e direitos individuais homogêneos, o que será feito utilizando-se dos ensinamentos de Leonardo Roscoe Bessa. Os primeiros se caracterizam por envolver direitos metaindividuais originários de um mesmo fato jurídico, cuja natureza seja indivisível, envolvendo pessoas indetermináveis (BESSA, 2016, p. 521). Em tal categoria se enquadra a tutela do meio ambiente ecologicamente equilibrado - bem difuso -, seja na intenção de prevenir danos ambientais ou para repará-los. 
Os segundos se relacionam com direitos transindividuais considerados indivisíveis, concernentes a um grupo de pessoas determináveis que detêm um vínculo jurídico entre si ou com a parte contrária (BESSA, 2016, p. 522). Como exemplo pode-se citar o caso de pescadores cujo trabalho é impossibilitado em razão de empreendimento que causa dano ambiental ao rio que utilizavam para exercer seu labor.

Por fim, o terceiro tipo de direito coletivo lato sensu diz respeito a direitos divisíveis pertencentes a um grupo de pessoas determinadas, que só podem (e recomenda-se) ser tratadas coletivamente porque têm origem num fato comum (BESSA, 2016, p. 524). Um bom exemplo de direito individual homogêneo consiste na reunião de diversas pretensões indenizatórias individuais decorrentes de dano moral causado por um mesmo fato jurídico, tal como a poluição de rio que serve como única fonte de água potável utilizada por determinado município, fazendo com que a população fique dias sem acesso à água encanada, que é um serviço público qualificado como essencial.

Em relação aos direitos coletivos (lato sensu) supramencionados, é interessante a colocação de Rodolfo Camargo Mancuso, em especial acerca dos individuais homogêneos e seu tratamento via ação coletiva:

Sob o prisma subjetivo, nos três subtipos há um núcleo comum: todos são interesses concernentes a coletividades numericamente expressivas, mas com diferenças sensíveis: os difusos concernem a sujeitos indeterminados e ligados por circunstâncias de fato; os coletivos em sentido estrito, conquanto também sejam referentes a sujeitos indeterminados, esse universo em certa medida relativiza, porque tais interesses se encontram coalizados num grupo, categoria ou classe, coalizados sob uma certa relação jurídica base; já os individuais homogêneos apenas são manejáveis coletivamente pelo fato de terem uma origem comum, que os aglutina e, assim, consente - ou até recomenda - um trato processual unitário; e também, porque, se tais interesses isomórficos fossem conduzidos ao plano da jurisdição singular, ter-se-ia um litisconsórcio ativo facultativo multitudinário, atritando o disposto no parágrafo único do art. 46 do CPC (MANCUSO, 2015, p. 47).

Importante ressaltar neste momento, mais uma vez valendo-se de informações fornecidas por Leonardo Roscoe Bessa, que em razão de uma equivocada interpretação literal do artigo $3^{\circ}$ da Lei 7.347/85, no passado se entendia que em ação civil pública não poderia haver cumulação de pedidos, pois de acordo com o citado dispositivo seu objeto deveria consistir na condenação de dinheiro ou o cumprimento de obrigação de fazer ou não fazer (BESSA, 2016, p. 527). O dispositivo em questão afirma que "A ação civil poderá ter por objeto a condenação em dinheiro ou o cumprimento de obrigação de fazer ou não fazer" (BRASIL, 1985).

Já há algum tempo, contudo, o Superior Tribunal de Justiça modificou o entendimento mencionado no parágrafo anterior, o que pode ser observado por ocasião do julgamento do recurso especial 105.215, em 24 de junho de 1997, que tramitou sob a relatoria do Ministro Sálvio de Figueiredo Teixeira (BRASIL, 1997). Nele, compreendeu-se que não se poderia interpretar 
restritivamente - de forma literal - a ação civil pública, não devendo dar tanta relevância à conjunção coordenativa "ou", constante no artigo $3^{\circ}$ da Lei $7.347 / 85$. Nesse sentido, afirmouse que o Ministério Público poderia pedir tanto pelo reconhecimento da nulidade de cláusula contratual abusiva quanto pela condenação ao pagamento de indenizações aos consumidores afetados (BRASIL, 1997).

Da mesma forma, como já frisado tantas vezes neste trabalho, também não se deve fazer uma interpretação restritiva do artigo $5^{\circ}$, inciso LXXIII da Constituição, o que diminuiria a efetividade da ação popular na tutela de bens que o cidadão tem a responsabilidade constitucional de defender e preservar.

Ao se ponderar acerca do conteúdo do artigo $225, \S 3^{\circ}$ da Constituição e do artigo $14, \S$ $1^{\circ}$ da Lei 6.938/81, deve-se concluir que em se tratando de dano ambiental, compete ao agente poluidor, além de recuperar o meio ambiente degradado - direito difuso -, indenizar terceiros afetados por sua atividade - direito coletivo stricto sensu ou individual homogêneo.

Art. 225. Todos têm direito ao meio ambiente ecologicamente equilibrado, bem de uso comum do povo e essencial à sadia qualidade de vida, impondo-se ao Poder Público e à coletividade o dever de defendê-lo e preservá-lo para as presentes e futuras gerações.

$\S 3^{\circ}$ As condutas e atividades consideradas lesivas ao meio ambiente sujeitarão os infratores, pessoas físicas ou jurídicas, a sanções penais e administrativas, independentemente da obrigação de reparar os danos causados (BRASIL, 1988).

Art 14 - Sem prejuízo das penalidades definidas pela legislação federal, estadual e municipal, o não cumprimento das medidas necessárias à preservação ou correção dos inconvenientes e danos causados pela degradação da qualidade ambiental sujeitará os transgressores:

$\S 1^{\circ}$ - Sem obstar a aplicação das penalidades previstas neste artigo, é o poluidor obrigado, independentemente da existência de culpa, a indenizar ou reparar os danos causados ao meio ambiente e a terceiros, afetados por sua atividade. $\mathrm{O}$ Ministério Público da União e dos Estados terá legitimidade para propor ação de responsabilidade civil e criminal, por danos causados ao meio ambiente. (BRASIL, 1981).

Atente-se que no dispositivo constitucional ficou dito que o poluidor será responsabilizado civilmente pelos danos causados, não tendo o constituinte realizado qualquer restrição quanto ao tipo de dano resultante da poluição. Por sua vez, a legislação infraconstitucional deixou evidente a necessidade do poluidor também ser responsabilizado pelos danos causados a terceiros, estando tal enunciado normativo em plena consonância com o texto constitucional.

Assim sendo, deve-se possibilitar, via ação popular ambiental, o manejo de pedidos relacionados à prevenção contra danos ambientais - obrigação de fazer ou de não fazer -, à recuperação do meio ambiente degradado - obrigação de fazer e condenação em dinheiro -, e também à obrigação de indenizar os danos causados a terceiros e/ou evitar o agravamento dos mesmos - condenação em dinheiro e/ou obrigação de fazer. 
Será possível, aliás, questionar a pertinência de atos que representem custo inadequado, desnecessário ou excessivo ao meio ambiente, realizando uma ponderação entre interesses colidentes com base no Princípio da Ecoproporcionalidade, o qual "Ao exigir a exposição de razões para os objetivos humanos e seus meios [...], contribui para um novo paradigma de regras que disciplinam a interação homem-natureza" (WINTER, 2013, p. 76-77).

Nesse sentido, convém trazer à tona o conteúdo do princípio 10 da Conferência Rio 92 - Princípio da Participação Comunitária -, ressaltando a importância de se garantir a todos os cidadãos efetivo acesso a mecanismos administrativos e judiciais, inclusive no que tange à compensação e reparação de danos:

A melhor maneira de tratar as questões ambientais é assegurar a participação, no nível apropriado, de todos os cidadãos interessados. No nível nacional, cada indivíduo terá acesso adequado às informações relativas ao meio ambiente de que disponham as autoridades públicas, inclusive informações acerca de materiais e atividades perigosas em suas comunidades, bem como a oportunidade de participar dos processos decisórios. Os Estados irão facilitar e estimular a conscientização e a participação popular, colocando as informações à disposição de todos. Será proporcionado o acesso efetivo a mecanismos judiciais e administrativos, inclusive no que se refere à compensação e reparação de danos. (ORGANIZAÇÃO NACIONAL DAS NAÇÕES UNIDAS, 1992)

A partir de determinado dano ambiental ou até mesmo de seu risco, decorrente de ato ou omissão lesiva ao meio ambiente, podem advir pretensões relativas a direitos difusos, coletivos stricto sensu e individuais homogêneos. Como quarta premissa, portanto, tem-se a concepção de que em se tratando de ação popular ambiental será possível a tutela de qualquer tipo de direito coletivo lato sensu, podendo o cidadão formular pedido de obrigação de fazer, de não fazer e/ ou condenatório, relacionado a qualquer dano ou perigo de dano que tenha origem na poluição ambiental ou em seu risco.

Ao se aplicar o entendimento que se expõe, estar-se-á prezando pelo bom funcionamento do Poder Judiciário ao se evitar a proliferação de demandas oriundas do mesmo fato jurídico, possuindo muitas vezes objeto idêntico. Com isso, será dada máxima eficácia a direitos fundamentais, em especial ao acesso à justiça e à defesa e preservação do meio ambiente ecologicamente equilibrado.

\section{CONCLUSÃO}

Ao se ponderar acerca das premissas estabelecidas nos tópicos anteriores, chega-se à conclusão de que a análise da amplitude do objeto ação popular ambiental tem como ponto de partida o teor do artigo 225 da Constituição. Tal garantia constitucional deve ser interpretada de forma ampliativa na intenção de se preservar e defender de maneira eficaz o direito ao meio ambiente ecologicamente equilibrado, haja vista sua essencialidade à sadia qualidade de vida.

Sob tal perspectiva o acórdão resultante da apelação cível 1.0672.14.032556-0/001 
reforçou a ideia de que a ação popular não poderia ser interpretada restritivamente, sendo possível a impugnação tanto de atos lesivos quanto de omissão lesiva ao meio ambiente. Diante da impossibilidade de se anular omissão lesiva, afirmou-se, por consequência, que o pedido de anulação de determinado ato não é imprescindível à ação popular ambiental.

A referida interpretação, que formará norma jurídica diante de casos concretos, deve prezar pela coerência e integridade do direito, garantindo unidade constitucional, enfatizando o conteúdo da soberania popular e dos valores do Estado Democrático de Direito, de modo a oportunizar uma ampla efetividade dos princípios da cidadania, da solidariedade,da dignidade da pessoa humana e da prestação jurisdicional adequada.

Ressaltou-se, também, que em se tratando de processo coletivo, deve-se atentar para a Teoria do Diálogo das Fontes, que deu origem ao "Microssistema do Processo Coletivo", cuja aplicação é reconhecida tanto pela doutrina quanto jurisprudência, e tem como núcleo normativo a Lei 7.347/85 (Lei de ação civil pública) e Lei 8.078/90 (Código de Defesa do Consumidor).

Ademais, da interpretação conjunta dos artigos $5^{\circ}$, inciso XXXV e 129, inciso III da Constituição, e artigo $1^{\circ}$, inciso IV da Lei 7.347/85, retira-se o Princípio da Não Taxatividade do Objeto Material da Ação Coletiva, que impede a limitação do objeto da ação coletiva. Tal princípio reforça a vedação à interpretação restritiva de garantias processuais constitucionais, sendo coerente com os enunciados contidos no artigo $225, \S 3^{\circ}$ da Constituição e artigo 14 , $\S 1^{\circ}$ da Lei 6.938/81.

Dessa forma, tal como ocorre com a ação civil pública, qualquer pedido atinente à prevenção de danos ambientais - mediante obrigação de fazer ou não fazer -, à sua reparação - obrigação de fazer, de não fazer, de pagar dinheiro -, ou à indenização de danos coletivos ou individuais (homogêneos) que tenham origem no dano ambiental - obrigação de dar dinheiro -, pode ser veiculado em ação popular ambiental.

Por se tratar de garantia fundamental essencial à tutela coletiva do risco (ameaça) de dano ou efetivo dano ao meio ambiente, o objeto ação popular ambiental não pode ser limitado ou vinculado ao pedido de anulação de ato lesivo, sendo possível também a tutela omissões lesivas ao meio ambiente ecologicamente equilibrado.

Assim, nos termos expostos, chega-se à conclusão de que em ação popular ambiental é cabível a formulação de pedidos de obrigação de fazer, de não fazer e de pagar dinheiro. Pode-se buscar a prevenção ou reparação de danos causados a direitos difusos, coletivos stricto sensu ou individuais homogêneos, desde que tenham origem em violação do direito fundamental ao meio ambiente ecologicamente equilibrado, que é essencial à sadia qualidade de vida. Tal perspectiva é imprescindível para proporcionar uma máxima efetividade à ação popular (garantia constitucional) e ao direito fundamental envolvido (meio ambiente).

\section{REFERÊNCIAS}

BESSA, Leonardo Roscoe. Ação coletiva. In: BENJAMIN, Antônio Herman V.; MARQUES, Claudia Lima; BESSA, Leonardo Roscoe. Manual de direito do consumidor. 7. ed. São Paulo: Editora Revista dos Tribunais, 2016. p. 515-557. 
BRASIL. Superior Tribunal de Justiça. Recursos repetitivos. Informativo de

Jurisprudência, Brasília, n. 568, 3 set. 2015. Disponível em: http://www.stj.jus.br/SCON/

SearchBRS?b=INFJ\&tipo=informativo\&livre=@COD=\%270568\%27. Acesso em: 14 abr. 2017.

BRASIL. [Constituição (1988)]. Constituição da República Federativa do Brasil. Brasília: Presidência da República, 1988. Disponível em: http://www.planalto.gov.br/ccivil_03/ constituicao/constituicao.htm Acesso em: 14 abr. 2017.

BRASIL. Lei no 4.717 de 29 de junho de 1965. Regula a ação popular. Brasília: Presidência da República, 1965. Disponível em: http://www.planalto.gov.br/ccivil_03/leis/L4717.htm. Acesso em: 14 abr. 2017.

BRASIL. Lei $\mathbf{n}^{\mathbf{0}}$ 6.938, de 31 de agosto de 1981. Dispõe sobre a Política Nacional do Meio Ambiente, seus fins e mecanismos de formulação e aplicação, e dá outras providências. Brasília: Presidência da República, 1981. Disponível em: http://www.planalto.gov.br/ccivil_03/leis/ L6938.htm. Acesso em: 14 abr. 2017.

BRASIL. Lei $\mathbf{n}^{0} \mathbf{7 . 3 4 7}$ de 24 de julho de 1985. Disciplina a ação civil pública de responsabilidade por danos causados ao meio-ambiente, ao consumidor, a bens e direitos de valor artístico, estético, histórico, turístico e paisagístico (VETADO) e dá outras providências. Brasília: Presidência da República, 1985. Disponível em: http://www.planalto.gov.br/ccivil_03/ leis/L7347orig.htm. Acesso em: 14 abr. 2017.

BRASIL. Lei $\mathbf{n}^{\mathbf{0}} \mathbf{8 . 0 7 8}$ de 11 de setembro de 1990. Dispõe sobre a proteção ao consumidor e dá outras providências. Brasília: Presidência da República, 1990. Disponível em: http://www. planalto.gov.br/ccivil_03/leis/L8078.htm. Acesso em: 14 abr. 2017.

BRASIL. Superior Tribunal de Justiça. Recurso Especial no 105215 - DF. Órgão Julgador: Quarta Turma. Relator: Ministro Sálvio de Figueiredo Teixeira. Data do Julgamento: 24 de junho de 1997. Disponível em: https://ww2.stj.jus.br/processo/ita/listarAcordaos?classe=\&num processo=\&num_registro=199600534551\&dt_publicacao=18/08/1997. Acesso em: 28 abr. $201 \overline{7}$.

BRASIL. Superior Tribunal de Justiça. Recurso Especial nº 889766 - SP. Órgão Julgador: Segunda Turma. Relator: Ministro Castro Meira. Data do Julgamento: 04 de outubro de 2007. Disponível em: https://ww2.stj.jus.br/jurisprudencia/externo/ informativo/ acao $=$ pesquisar $\&$ processo $=889766 \&$ operador $=e \& b=I N F J \&$ thesaurus $=$ JURIDICO. Acesso em: 28 abr. 2017.

BRASIL. Supremo Tribunal Federal. Ação Direta de Inconstitucionalidade $\mathbf{n}^{\mathbf{0}}$ 2591- DF. Órgão Julgador: Tribunal Pleno. Relator: Ministro Carlos Velloso. Relator para Acórdão: Ministro Eros Grau. Julgamento: 7 de julho de 2006. Disponível em: http://www.stf.jus.br/portal/processo/verProcessoAndamento.as $\mathrm{p}$ ? numero $=2591 \&$ classe $=A D I \&$ codigoClasse $=0$ \&origem $=J U R \&$ recurso $=0 \&$ tipoJulgamento $=\mathrm{M}$. Acesso em: 28 abr. 2017.

BRASIL. Supremo Tribunal Federal. Recurso Extraordinário nº 441318 - DF. Órgão Julgador: Primeira Turma. Relator: Ministro Marco Aurélio. Data do Julgamento: 25 de outubro de 2005. Disponível em: http://www.stf.jus.br/portal/processo/verProcessoAndamento. ?numero $=441318 \&$ classe $=$ RE \& codigoClasse $=0$ \&origem $=J U R \&$ recurso $=0 \&$ tipoJulgamento $=\mathrm{M}$. Acesso em: 28 abr. 2017. 
CHRISTMANN, Luiza Landerdahl. Democracia deliberativa e participação popular no licenciamento ambiental do OSX-Estaleiro/SC: desafios e possibilidades. Revista Veredas do Direito: direito ambiental e desenvolvimento sustentável, Belo Horizonte, v. 10, n. 20, p. 111-145, 2013. Disponível em: http://www.domhelder.edu.br/revista/index.php/veredas/issue/ view/31/showToc. Acesso em: 14 abr. 2017.

MANCUSO, Rodolfo de Camargo. Ação popular. 8. ed. São Paulo: Editora Revista dos Tribunais, 2015.

MARINONI, Luis Guilheme; MITIDIERO, Daniel. Ações constitucionais. In: SARLET, Ingo Wolfgang; MARINONI, Luiz Guilherm; MITIDIERO, Daniel. Curso de direito constitucional. 2. ed. São Paulo: Editora Revista dos Tribunais, 2013.

MARQUES, Claudia Lima. Diálogo das fontes. In: BENJAMIN, Antônio Herman V.; MARQUES, Claudia Lima; BESSA, Leonardo Roscoe. Manual de direito do consumidor. 7. ed. São Paulo: Editora Revista dos Tribunais, 2016. p. 135-153.

MINAS GERAIS. Tribunal de Justiça de Minas Gerais. Apelação Cível no 1.0672.14.0325560/001 - MG. Órgão Julgador: $2^{a}$ Câmara Cível. Relator: Desembargador Raimundo Messias Júnior. Data de Julgamento: 07 de fevereiro de 2017. Disponível em: http:// www5.tjmg.jus.br/jurisprudencia/pesquisaNumeroCNJEspelhoAcordao.do?numero Registro $=1 \&$ totalLinhas $=1 \&$ linhasPorPagina $=10 \&$ numeroUnico $=1.0672 .14 .032556$ 0\%2F001\&pesquisaNumeroCNJ=Pesquisar. Acesso em: 28 abr. 2017.

MINAS GERAIS. Tribunal de Justiça. Apelação Cível no 1.0342.12.013524-5/002 - MG. Órgão Julgador: $4^{\mathrm{a}}$ Câmara Cível. Relator: Desembargadora Heloísa Combat. Julgamento: 22 jan. 2015. Disponível em: http://www5.tjmg.jus.br/jurisprudencia/ pesquisaNumeroCNJEspelhoAcordao.do?numeroRegistro=1\&totalLinhas=1\&linhasPorPagina= $10 \&$ numeroUnico $=1.0342 .12 .013524-5 \% 2 \mathrm{~F} 002 \&$ pesquisaNumeroCNJ=Pesquisar. Acesso em: 28 abr. 2017.

OLIVEIRA, Adauto José de. Ação popular ambiental. Belo Horizonte: Arraes Editores, 2011.

ORGANIZAÇÃO DAS NAÇÕES UNIDAS. Declaração do Rio sobre Meio ambiente e desenvolvimento. Rio de Janeiro: ONU, 1992. Disponível em: http://www.onu.org.br/rio20/ img/2012/01/rio92.pdf. Acesso em: 14 abr. 2017.

SAMPAIO, José Adércio Leite. Direito fundamental ao meio ambiente saudável, adequado e ecologicamente equilibrado. In: SAMPAIO, José Adércio Leite; WOLD, Chris; NARDY, Afrânio. Princípios de direito ambiental. Belo Horizonte: Del Rey, 2003. p. 89-111.

WINTER, Gerd. Proporcionalidade "eco-lógica": um princípio emergente para a natureza? Revista Veredas do Direito: direito ambiental e desenvolvimento sustentável, Belo Horizonte, v. 10, n. 20, p. 55-79, 2013. Disponível em: http://www.domhelder.edu.br/revista/index.php/ veredas/issue/view/31/showToc. Acesso em: 14 abr. 2017.

Como citar: GUSMÃO, Leonardo Cordeiro de; COSTA, Beatriz Souza. A extensão do objeto da ação popular ambiental diante do microssistema do processo coletivo. Revista do Direito Público, Londrina, v. 14, n. 1, p. 160-178, abr. 2019. DOI: 10.5433/1980-511X2019v14n1p160. 
ISSN: 1980-511X.

Recebido em: 29/05/2017.

Aprovado em: 14/01/2019. 